1 Newman SP, Pavia D, Moren F, Sheahan NF, Clarke SW. Deposition of pressurised aerosols in the human respiratory tract. Thorax $1981 ; 36: 52-5$.

2 Zainudin BMZ, Biddiscombe M, Tolfree SEJ, Short MD, Spiro SG. Comparison of bronchodilator responses and deposition patterns of salbutamol inhaled from a pressurised metered dose inhaler, as a dry powder, and as a nebulised solution. Thorax 1990;45:469-73.

3 Short MD, Singh CA, Few JD, Studdy PR, Heaf PJD, Spiro SG. The labelling and monitoring of lung deposition of an inhaled synthetic anticholinergic bronchodilating agent. Chest 1981;80(Suppl):918-21S.

4 Köhler D, Fleischer W, Matthys $H$. New method for easy labelling of $\beta_{2}$ agonists in the metered dose inhaler with technetium-99m. Respiration 1988;53:65-73.

5 Newman SP, Clark AR, Talaee N, Clarke SW. Pressurised aerosol deposition in the human lung with and without an "open" spacer device. Thorax 1989;44:706-10.

6 Newman SP, Weisz AWB, Talaee N, Clarke SW. Improvement of drug delivery with a breath actuated pressurised aerosol for patients with poor inhaler technique. Thorax 1991;46:712-6.

7 Biddiscombe MF, Melchor R, Mak VHF, Marriott RJ, Taylor AJ, Short MD, et al. The lung deposition of salbutamol, directly labelled with technetium-99m, delivered by pressurised metered dose and dry powder inhalers. Int $\mathcal{F}$ Pharm 1993 (in press)

8 Newman SP, Pavia D, Garland N, Clarke SW. Effects of various inhalation modes on the deposition of radioactive pressurised aerosols. Eur $\mathcal{f}$ Respir Dis 1982; 63(Suppl): 119 .

9 Dolovitch MB, Ruffin RE, Roberts R, Newhouse MT. Optimal delivery of aerosols from metered dose inhalers. Chest 1981;80(Suppl):911-5.

10 Matthys H, Eltschka R, App EM. Deposition of a labelled $\beta_{2}$ agonist aerosol. Atemwlungenkrkn 1988;14:485-8.

11 Ashworth HL, Wilson CG, Sims EE, Wotton PK, Hardy

JG. Delivery of propellant soluble drug from a metered dose inhaler. Thorax 1991;46:245-7.

12 Clarke SW. Inhaler therapy. $Q \mathcal{F}$ Med 1988;67:355-68.

\title{
Adventitia
}

\section{Asthma and the psyche}

John was a scruffy, doe eyed lad of 13 admitted with acute asthma. It was his 12 th admission, all the previous ones being under a paediatrician. My registrar noted that he improved very quickly and he was prompted to look for precipitating factors. He found none and I also had a go at John with similar results. He was well when he went home. Two days later he was back with another attack which was again shortlived. John assured me that there were no problems at home or at school, but at a second talk he burst into tears and said: "Well, if you want to know, I hate my mum." Mum was a poor widow, big and fat, and with a terrible squint. At night she went to the pub to wash up. At school John was ashamed of his poor clothes and shoes (it was long before torn jeans became fashionable). Other boys had nice presents at Christmas and on birthdays but John had none. His sister had young children and when her lorry driver husband was away on long journeys, John babysat so that she could "carry on" elsewhere. He felt ashamed of her activities, as he was of his mother's job.

After a couple of days he said he was ready to go home and that he wouldn't get asthma again. On the way home he ran away from his mother and later he telephoned me. I picked him up and took him home with me for crumpets and tea, after which John was in hospital for the 14 th time.

After a few more crises it was decided that he should be found foster parents. His new mother was also fat but had no squint. She was well dressed and exuded warmth. John lost his asthma and eczema.

Five years later he was admitted again. $\mathrm{He}$ was working but had quarrelled with his foster mother and gone back to his old home. A few weeks later his asthma and eczema were bad again. No, I don't think it had anything to do with the house dust mite.

Mr West, a sock manufacturer, developed asthma when he was 47 and was admitted with a bad attack which was resistant to treatment. The sister mentioned that his wife and secretary visited at different times and that he seemed to be worse after such visits. After probing he also burst into tears. His secretary was his mistress and during their liaison she had acquired half his business so he could not get rid of her, as he now wanted to. He accepted that anger, fear, and frustration were precipitants of his asthma and, after a troublesome year, peace and contentment were somehow restored and he became much better.

Some six years later I was standing at a bus stop. He drove by and stopped to pick me up. Our journey was long enough to establish that he was free of asthma but not to find out how peace had been achieved. He made very good socks and I still have a pair of them in a drawer.

I met these cases long ago, but since then I have never recognised such a clear connection between psyche and asthma. How many have I missed? As a young consultant I spent all my working hours on the wards and in outpatients. As the years went by other matters took up time and more layers of junior staff intruded between me and my patients. These days continuity of care seems even worse, with more of a consultant's time being occupied away from patients. Most asthmatics attending hospitals are likely to be seen by different doctors on most occasions. The accent seems to be increasingly on medication with scant regard for causation.

D DAVIES 